\title{
Flipped Classroom: A Paradigm Shift in English Language Teaching
}

\author{
M. Rakesh Babu, S. Vivekha
}

\begin{abstract}
The paper entitled "Flipped Classroom: A Paradigm Shift in English Language Teaching" discusses about the need of flipping the English language classroom. The flipped classroom is a teaching model which is now being flourished around the globe. Implementation of the flipped classroom doesn't cost much but it demands the instructor to prepare herself with a video lecture before the class. The classroom activity keeps aside the lecturing part and is meant for activities. The paper tries to emphasize the need of implementing flipped classrooms in English language teaching. It elucidates how this language teaching model is different from the traditional language teaching methodologies. It also puts forth the pros and cons of the new teaching model.
\end{abstract}

Keywords--- Flipped Classroom, Video, Activities, Worksheet, Feedback, and Learner Autonomy.

\section{INTRODUCTION}

The concept of the flipped classroom is not new in the field of English Language Teaching. It has been around for a number of years. When it emerged in the field of language teaching it attracted the attention of educators. Jon Bergmann and Aaron Sam are some of the pioneers of the flipped classroom. A flipped classroom cannot be defined in a single term. It keeps on changing, here giving a constant definition is not an easy task. In a flipped class the traditional way of teaching is reversed, what is done in the home is done in the classroom and vice versa [5]. The time and the place of lecturing are flipped. The classroom which is meant for listening in the conventional classroom is metamorphosed as learning or activity center.

\section{DISCUSSIONS \& RESULTS}

The flipped classroom or the inverted classroom is a type of blended learning in which the instructional part is done online and the feedback is given in the classroom. It establishes a framework that ensures students receive personalized education[2]. The traditional language teacher who is considered as the knowledge giver now takes the role of the facilitator. The paper throws light on the benefits and the drawbacks of the inverted classroom.

\section{Benefits of flipped classroom}

The flipped classroom brings an array of advantages on its way. Instant feedback, less dependency on the materials, low budget is some of the benefits of this setup. The paper lists out the benefits vividly.

Revised Manuscript Received on July 10, 2019.

M. Rakesh Babu, Department of English, Noorul Islam Centre for Higher Education, Kanyakumari, T.N, India. (e-mail: rakeshbabukarthika@gmail.com)

S. Vivekha, Research Scholar in English, Noorul Islam Centre for Higher Education, Kanyakumari, T.N, India. (e-mail: ltr2vetha@gmail.com)

\section{Students get help on tough topics}

In the conventional classroom the learner is forced to lend his ears to the boring lectures and he marches towards his home with a bundle of assignments from the lectures given. While doing the assignments in order to clarify his doubts he ought to ask the teacher the next day or call a friend or simply cheat. But in the flipped classroom the student who watches the lecture at home is asked to do the homework in the class where the facilitator will be readily waiting to assist him. The key element of this model is that students get instant feedback from the facilitator.

\section{The teacher-student interaction is enhanced}

In the traditional classroom setup, the teacher keeps on talking for hours and the students tend to act like they were listening or else the students are the passive listeners. Usually there is no scope for conversation and there is only one-way communication. If the teacher interacts with the students during lectures the class will be lively and rich in content as well as communication. But the 'chalk and talk' method of language teaching keeps the students busy in taking notes. In contrast to the traditional classes the flipped classroom gives ample opportunities for the facilitator to communicate with each and every student during the class hours. Since the facilitator becomes familiar with the students they can categorize their abilities and give them apt challenge accordingly. It also changes the distribution of teacher's time [4].

\section{Scaffolds in building the learner autonomy}

The inverted classroom creates an atmosphere of learning where the learners are the owners of their learning process and the ownership pushes them forward to glide away from the position of passive listeners to attain the position of active learners. In the classroom lecture the slow learners feel the lecture to be fast and are left behind. If the teacher teaches slowly for their sake the fast learner gets bored. For the betterment of both these categories the videos in the flipped classroom module is made in a moderate speed which benefits all. To their advantage the students can pause or rewind the videos or play them as many times as possible and the content at their own pace.

\section{Absence doesn't count}

In the flipped classroom absence of both the teacher and the student doesn't cost much. Lessons can be learnt both in the teacher's and the students' absence. If a student is absent the teacher is not forced to re-teach him in the same way, the student too won't pester the teacher to re-teach him the missed lesson.

Published By.

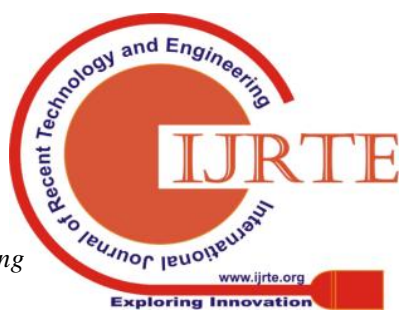


The student can watch the videos of the missed class and the teacher can also pre engage the students for the to be missed class with some short videos.

\section{The student teacher relationship gets better.}

The flipped classroom replaces the teacher from the centre. It makes the teacher to become one among the student. In the traditional classrooms while giving lectures the teacher can only see the blinking and winking eyes of the students, but not their abilities, struggles and fears. In the new set up when the facilitator is on with the students they can understand them better as individuals and can offer them timely help.

\section{Drawbacks of the flipped classroom}

Implementing a completely new methodology in language teaching and learning is not at all an easy task. It needs some sort of laboriousness and financial requirements. Having those things in mind the paper tries to list out the limitations too.

\section{Students tend to cheat}

All students won't properly do the stipulated take home assignments in the traditional language learning classes. The flipped classroom is also not an exception. Engaging reluctant students continues to be a challenge [1]. Making all the students to watch the videos is not possible. To ensure that the students have watched the videos the facilitator insists them on taking notes on the uploaded video or he can monitor the viewership in the webpage. Students who haven't watched the video are sent to the backyard of the class to watch them in the computer while other were doing their activities. Though students realize it is better to do their homework from their home, they are a step back in their progress.

\section{Technology turns out to be a barrier}

A very high budget is not needed in setting up a flipped classroom. It can be done with some basic techno aids such as an updated computer, internet connection, webcam or a video camera. Students too won't need much expensive technologies. A smartphone or a laptop or a computer with internet connection can do but relying too much on technology can turn out to be a barrier indeed. Technology can stab your back in many cases. If technology breaks out the teacher must roll back herself back to the traditional 'walk and talk' method of language teaching.

\section{Students get addicted to the technologies}

One of the major drawback of the flipped classroom is that parents complain that their kids are wasting too much of their time simply sitting in front of the computer screen. Parents can't find whether their children are playing or learning. This method sometimes flips the role of parents to a watchdog.

\section{Will it replace the teacher?}

The major concern about this classroom is that students see technology as a replacement of their teacher. If we want to simply educate them, we can educate them with the video content. But besides from teaching a language a student teacher relationship is about caring which any technology can't offer. It can be labour intensive [3]. In order to make them thoughtful creative and to teach them the moral values the teacher should spend some time with them besides doing the activities.

\begin{tabular}{|l|l|l|l|}
\hline \multicolumn{2}{|c|}{ Traditional classroom } & \multicolumn{2}{c|}{ Flipped classroom } \\
\hline $\begin{array}{l}\text { Inside the } \\
\text { class }\end{array}$ & Lecture & $\begin{array}{l}\text { Inside the } \\
\text { class }\end{array}$ & $\begin{array}{l}\text { Activities and } \\
\text { feedback }\end{array}$ \\
\hline $\begin{array}{l}\text { Outside the } \\
\text { class }\end{array}$ & $\begin{array}{l}\text { Assignments and } \\
\text { home work }\end{array}$ & $\begin{array}{l}\text { Outside the } \\
\text { class }\end{array}$ & Video lectures \\
\hline
\end{tabular}

\section{CONCLUSION}

The flipped classroom has changed the teaching and learning methodology. The paper firmly holds the view that the teacher is able to know the students more than even before and the needs of the students are met. Flipping some classes or completely flipping the classes should be encouraged. The paper adds on that the concept may appear to be simple but it can bring forward amazing results.

\section{REFERENCES}

1. Ash,k.(2012). Education View 'Flipped' Model with A More Critical Eye. Education Week,32 (2).

2. Bergmann, H. \& Sams, A. (2012). Flip Your Classroom: Reach Every Student in Every Class Every Day. Alexandria, VA: International Society for Technology in Education: ASCD.

3. Beret, D.(2012). How 'Flipping' The Classroom Can Improve the Traditional Lecture. Chronicle of Higher Education. 58 (25).

4. Evans, D. (2011) Turning lessons upside down. Times Educational Supplement. p.4.

5. Flipped classroom offers new learning path(2011). Electronic Education Report. 18, (23),1-3. 